\title{
Effects of jugular-infused lysine, methionine, and branched-chain amino acids on milk protein synthesis in high-producing dairy cows
}

\author{
J. A. D. R. N. Appuhamy, ${ }^{\star}$ J. R. Knapp,† O. Becvar,‡ J. Escobar,§ and M. D. Hanigan*1 \\ *Department of Dairy Science, Virginia Polytechnic Institute and State University, Blacksburg 24061 \\ †Fox Hollow Consulting, LLC, Columbus, OH 43201 \\ ‡Department of Large Animal Clinical Sciences, Virginia-Maryland Regional College of Veterinary Medicine, \\ Virginia Polytechnic Institute and State University, Blacksburg 24061 \\ §Department of Animal and Poultry Sciences, Virginia Polytechnic Institute and State University, Blacksburg 24061
}

\section{ABSTRACT}

In addition to lysine and methionine, current rationbalancing programs suggest that branched-chain amino acid (BCAA) supply may also be limiting in dairy cows. The objective of this study was to investigate whether BCAA, leucine, isoleucine, and valine become limiting for milk protein synthesis when methionine and lysine supply were not limiting. Nine multiparous Holstein cows with an average milk production of $53.5 \pm 7.1$ $\mathrm{kg} / \mathrm{d}$ were randomly assigned to 7-d continuous jugular infusions of saline (CTL), methionine and lysine (ML; $12 \mathrm{~g}$ and $21 \mathrm{~g} / \mathrm{d}$, respectively), or ML plus leucine, isoleucine, and valine (ML+BCAA; $35 \mathrm{~g}, 15 \mathrm{~g}$, and 15 $\mathrm{g} / \mathrm{d}$, respectively) in a $3 \times 3$ Latin square design with 3 infusion periods separated by 7 -d noninfusion periods. The basal diet consisted of $40 \%$ corn silage, $14 \%$ alfalfa hay, and a concentrate mix, and respectively supplied lysine, methionine, isoleucine, leucine, and valine as 6.1, $1.8,4.7,8.9$, and $5.3 \%$ of metabolizable protein. Dry matter intake $(23.9 \mathrm{~kg} / \mathrm{d})$, milk yield $(52.8 \mathrm{~kg} / \mathrm{d})$, fat content $(2.55 \%)$, fat yield $(1.33 \mathrm{~kg} / \mathrm{d})$, lactose content $(4.77 \%)$, lactose yield $(2.51 \mathrm{~kg} / \mathrm{d})$, and milk protein efficiency $(0.38)$ were similar across treatments. Protein yield and protein content were not significantly different between ML $(1.52 \mathrm{~kg} / \mathrm{d}$ and $2.88 \%$, respectively) and ML+BCAA $(1.51 \mathrm{~kg} / \mathrm{d}$ and $2.83 \%$, respectively), but they were significantly greater than that of CTL (1.39 $\mathrm{kg} / \mathrm{d}$ and $2.71 \%$ ). Cows that received ML+BCAA had less milk urea nitrogen content $(10.9 \mathrm{mg} / \mathrm{dL})$ compared with milk of CTL cows $(12.4 \mathrm{mg} / \mathrm{dL})$ and ML cows $(11.8 \mathrm{mg} / \mathrm{dL})$. Whereas high-producing cows responded positively to methionine and lysine supplementation, no apparent benefits of BCAA supplementation in milk protein synthesis were found. Infusion of BCAA may have stimulated synthesis of other body proteins, prob-

Received May 16, 2010.

Accepted December 13, 2010.

${ }^{1}$ Corresponding author: mhanigan@vt.edu ably muscle proteins, as evidenced by decreased milk urea nitrogen.

Key words: methionine, lysine, branched-chain amino acid, milk protein synthesis

\section{INTRODUCTION}

Branched-chain amino acids (BCAA) are taken up by the mammary gland and used for cellular and milk protein synthesis, and provision of metabolic intermediates and energy (Wohlt et al., 1977; Mackle et al., 1999; Li et al., 2009). Branched-chain AA comprise $50 \%$ of the essential AA in milk proteins (Mackle et al., 1999). Current ration-balancing software (NRC, 2001 and CPM-Dairy V3.0, Ithaca, NY) suggest that the BCAA may be as limiting as methionine and lysine for high-producing dairy cows (>40 kg of milk/d) fed rations with large proportions of corn silage, corn grain, and corn byproducts. Also, there may be a limit to how much BCAA can be mobilized from muscle to the mammary glands. Weekes et al. (2006) fed a 9\%-CP diet supplemented with either casein or an AA mixture devoid of BCAA via abomasal infusion. No decrease in milk yield or milk protein concentration occurred after the 6-d incomplete AA mixture infusion. However, serum levels of leucine fell to $60 \%$ of basal values in cows infused with the BCAA-deprived mixture. Similar decreases in serum BCAA concentrations have been observed with increasing milk protein synthesis in response to hyperinsulinemic-euglycemic clamp studies (McGuire et al., 1995; Griinari et al., 1997).

Evidence for the effects of BCAA supplementation on milk protein synthesis is mixed and appears to be dependent on the characteristics of the experimental diets. Mackle et al. (1999) observed no milk yield or milk composition responses to abomasal infusions of BCAA when cows were fed diets to exceed ME and MP requirements, suggesting that increasing the supply of AA to the mammary glands above the requirements for milk synthesis and tissue metabolism does not further increase milk protein yields. Hopkins et al. (1994) in- 
fused a mixture of BCAA intraperitoneally into lactating cows fed low-CP diets and observed no effects on milk yield or milk composition. An evaluation of those diets suggests that lysine, methionine, and histidine, in addition to the BCAA, may have been limiting for milk synthesis. Rulquin and Pisulewski (2006) observed significant increases in milk protein yields and contents in response to duodenal infusions of leucine in cows fed a corn silage-based diet. These cows were additionally infused with a leucine-deprived AA mixture supplying lysine and methionine above their requirements for milk production. Supplementation of methionine and lysine improved milk protein synthesis in dairy cows fed corn ingredient-based diets (Donkin et al., 1989; Weekes et al., 2006). Combined supplementation of rumen-protected lysine and methionine can increase milk protein content and conversion efficiency of dietary protein to milk protein (Noftsger and St-Pierre, 2003; Vyas and Erdman, 2009).

Branched-chain AA, in particular leucine, stimulate muscle protein synthesis and also inhibit muscle protein degradation (Bolster et al., 2004; Escobar et al., 2006; Shimomura et al., 2006). Decreased muscle protein degradation would be characterized by decreased plasma 3-methylhistidine levels (Hillgartner et al., 1981). Moshel et al. (2006) reported that protein synthesis rates in bovine mammary epithelial cells were responsive to multiple AA, in addition to leucine. Moreover, in lactating sows, dietary supplementation of isoleucine increased the casein fraction of milk protein (Richert et al., 1997) and valine increased weaning litter weights (Moser et al., 2000).

The present experiment was designed to determine whether BCAA, isoleucine, leucine, and valine, become limiting for milk protein synthesis in high-producing dairy cows $(>40 \mathrm{~kg}$ milk/d) fed rations based on corn silage, corn grain, and corn ethanol byproducts when methionine and lysine are not limiting. Additionally, the effects of BCAA supply on AA mobilization from muscle tissues of the dairy cows were investigated by measuring plasma 3-methylhistidine levels. As milk protein synthesis efficiencies increase with production level of cows (Nadeau et al., 2007), we expected to see significant milk protein synthesis responses for BCAA supplementation in these high-producing cows.

\section{MATERIALS AND METHODS}

\section{Animals and Treatments}

All animal procedures in this study were conducted under approval of the Virginia Tech Animal Care and Use Committee. Nine multiparous Holstein cows with an average milk production of $53.5 \mathrm{~kg} / \mathrm{d}$ and average
BW of $611 \mathrm{~kg}$ at 43 DIM at the beginning of the study were chosen. Cows were housed in a freestall barn when not receiving infusions and in individual metabolic stalls when receiving infusions. Cows were fed ad libitum to achieve a minimum of $5 \%$ refusals on an as-fed basis and were given free access to water. Individual daily feed intake and refusals were measured throughout the study. Cows were milked 2 times/d.

Cows were fed a common diet (Table 1) throughout the study and were adjusted to the diet for $14 \mathrm{~d}$ before the first infusion. The diet was formulated to meet or exceed all nutrient requirements for a 635-kg Holstein cow producing $43.2 \mathrm{~kg}$ of milk containing $3.80 \%$ milk fat and $3.0 \%$ true protein except for methionine, lysine, and BCAA, using CPM-Dairy 3.0 and was evaluated according to NRC (2001). As formulated in CPMDairy, the basal diet was expected to provide $107 \%$, $104 \%$, and $97 \%$ of methionine, lysine, and BCAA requirements, respectively. Infusions were designed to deliver methionine and lysine at $130 \%$ and $115 \%$ of CPM-predicted requirements, respectively, to ensure that these 2 AA did not limit responses. These levels of methionine and lysine in the methionine plus lysine (ML) treatment were 2.3 and $6.8 \% \mathrm{MP}$, respectively, according to NRC (2001). These levels have been shown in prior research to provide good, although possibly not maximal, responses in milk protein yields (Guinard and Rulquin, 1994; Noftsger and St-Pierre, 2003; Cho et al., 2007). The same absolute levels of methionine and lysine supplementation were used in the ML plus leucine, isoleucine, and valine (ML+BCAA) treatment, although as a \% of MP, they were diluted by the addition of $60 \mathrm{~g}$ of BCAA. Branched-chain AA were infused to achieve $110 \%$ of CPM-predicted requirements.

Cows were randomly assigned to an infusion sequence with treatments arranged in a $3 \times 3$ Latin square design. Treatments were 7 -d continuous jugular infusions of $0.9 \%$ saline (Baxter, Deerfield, IL) as the control treatment (CTL), ML, and ML+BCAA. To minimize carryover effects, treatment periods were separated by 7-d noninfusion periods. Milk, blood, and feed samples were obtained after $4 \mathrm{~d}$ of infusion. Rulquin and Pisulewski (2006) reported that milk protein responses to AA supplementations can be detected within $3 \mathrm{~d}$ of the start of infusion. Milk samples were also obtained at 5,6 , and $7 \mathrm{~d}$ of the noninfusion period preceding each infusion to determine whether carry-over effects of treatments occurred.

Pharmaceutical-grade L-lysine, L-methionine, Lleucine, L-isoleucine, and L-valine were obtained from Ajinomoto USA, Inc. (Raleigh, NC). Solutions were prepared by dissolving $21 \mathrm{~g}$ of lysine and $12 \mathrm{~g}$ of methionine in $2 \mathrm{~L}$ of $0.9 . \%$ saline for the ML treatment and $21 \mathrm{~g}$ of lysine, $12 \mathrm{~g}$ of methionine, $35 \mathrm{~g}$ of leucine, $15 \mathrm{~g}$ 
Table 1. Ingredient and chemical composition, and predicted supplied and required amounts of $\mathrm{NE}_{\mathrm{L}}$ and $\mathrm{MP}$ of the basal ration fed to all cows

\begin{tabular}{|c|c|}
\hline Diet & Quantity \\
\hline $\mathrm{DM}(\mathrm{g} / \mathrm{kg})$ & 556.7 \\
\hline \multicolumn{2}{|l|}{ Ingredient ( $\mathrm{g} / \mathrm{kg}$ of $\mathrm{DM})$} \\
\hline Corn silage & 396 \\
\hline Alfalfa hay & 144 \\
\hline Corn grain, ground & 180 \\
\hline Corn dry distillers grains & 90 \\
\hline Wheat middlings & 63 \\
\hline Soyplus ${ }^{1}$ & 36 \\
\hline Soybean meal & 36 \\
\hline Soybean hulls & 36 \\
\hline Calcium carbonate & 9.0 \\
\hline Sodium bicarbonate & 4.5 \\
\hline Salt & 4.0 \\
\hline Urea & 0.8 \\
\hline Vitamins and minerals $^{2}$ & 0.7 \\
\hline \multicolumn{2}{|c|}{ Nutrient composition (g/kg of DM) } \\
\hline $\mathrm{CP}$ & 160.8 \\
\hline $\mathrm{ADF}$ & 179.9 \\
\hline $\mathrm{NDF}$ & 316.3 \\
\hline Lignin & 22.13 \\
\hline Starch & 283.3 \\
\hline Fat & 36.45 \\
\hline Ash & 53.56 \\
\hline \multicolumn{2}{|l|}{ Nutrient supply ${ }^{3}$} \\
\hline $\mathrm{NE}_{\mathrm{L}}(\mathrm{Mcal} / \mathrm{d})$ & 38.3 \\
\hline $\operatorname{MP}(g / d)$ & 2,733 \\
\hline \multicolumn{2}{|l|}{ Nutrient requirement $^{3}$} \\
\hline $\mathrm{NE}_{\mathrm{L}}(\mathrm{Mcal} / \mathrm{d})$ & 40.4 \\
\hline $\mathrm{MP}(\mathrm{g} / \mathrm{d})$ & 2,918 \\
\hline
\end{tabular}

${ }^{1}$ West Central Coop., Ralston, Iowa.

${ }^{2}$ Vitamin A, D, E, magnesium oxide, manganous oxide, zinc oxide, hydrated sulfate, cobalt carbonate, ferrous sulfate, copper sulfate.

${ }^{3}$ Calculated using the NRC (2001) model and observed input values.

of isoleucine, and $15 \mathrm{~g}$ of valine in $2 \mathrm{~L}$ of $0.9 . \%$ saline for the ML+BCAA treatment. Solutions were filter sterilized through $0.22-\mu \mathrm{m}$ membrane filters (Millipore, Billerica, MA). Infusates for each period were prepared $2 \mathrm{~d}$ before the start of the period and refrigerated until use. On d 1 of each treatment period, cows were aseptically fitted with indwelling jugular polyvinyl chloride catheters (1.5-mm o.d.; Ico-Rally Corp., Palo Alto, CA; catalog no. SVL 105-18CLR). Infusates were delivered at a rate of $2 \mathrm{~L} / \mathrm{d}$ using clinical infusion pumps (Abbott Lifecare, San Antonio, TX; model RF-5000). Exact weights of bags before and after infusions and bag change times were recorded.

\section{Sampling and Chemical Analysis of Feed and Milk}

Milk samples were collected from each milking during the last $3 \mathrm{~d}$ of each treatment period. Milk samples were analyzed at the United Federation of DHIA Laboratory (Blacksburg, VA) for true protein, fat, and lactose concentrations and SCC using a Fossomatic 4000 Combi infrared analyzer (Foss, Eden Prairie, MN). Milk urea nitrogen concentrations were determined using a modified Berthelot procedure (ChemSpec 150 Analyzer; Bentley Instruments, Chaska, MN).

Samples of corn silage, alfalfa hay, concentrate mix, and TMR of individual cows were collected on 3 consecutive days at the end of each period and stored at $-20^{\circ} \mathrm{C}$ until analysis. All feed samples were dried at $60^{\circ} \mathrm{C}$ until a constant dry weight was obtained. Composites were ground through a 1-mm screen of a Wiley mill (Arthur H. Thomas Co., Philadelphia, PA) and submitted for analyses at Dairyland Laboratories, Inc. (Arcadia, WI). Kjeldahl N, ether extract, ash, and DM contents were determined according to AOAC methods (AOAC, 1997). Acid detergent fiber and lignin concentrations were determined according to AOAC (1997; method 973.18) and NDF concentration according to Van Soest et al. (1991). Starch was measured as dextrose after treating samples with glucoamylase using a YSI 2700 Select Biochemistry Analyzer (Application Note \#319, Yellow Springs, OH). Minerals were quantified according to AOAC methods (1997; method 985.01) using an inductively coupled plasma spectrometer (Thermo Jarrell Ash, Franklin, MA). Nutrient composition values presented in Table 1 are average values of TMR sample analyses and calculated nutrient composition values based on the individual ingredient analyses and dietary inclusion rates.

\section{Blood Plasma Analysis for Essential AA and 3-Methyl-Histidine}

Blood samples were obtained from coccygeal vessels into heparinized vacutainers (Preanalytical Solutions, Franklin Lakes, NJ) at 0800 and $2000 \mathrm{~h}$ on the last 2 d of each infusion period. Blood samples were stored on ice, centrifuged $\left(1000 \times g, 10 \mathrm{~min}\right.$, and $\left.4^{\circ} \mathrm{C}\right)$ and the plasma was stored at $-20^{\circ} \mathrm{C}$. Plasma essential AA (EAA) concentrations were determined by isotopic dilution using a gas chromatograph coupled to a mass spectrometer (GC-MS, Thermo Scientific, Waltham, MA: GC model: Focus; MS model: PlolarisQ) as described previously by El-Kadi et al. (2006).

Muscle protein mobilization was determined by measuring plasma 3-methylhistidine concentrations using HPLC. Briefly, glass vials (Kimble Glass Inc., Vineland, NJ) containing $25 \mu \mathrm{L}$ of plasma were deproteinized using spin columns with a $10,000 \mathrm{kDa}$ molecular weight cutoff (PALL Life Sciences, Hauppauge, NY) at 14,000 $\times$ $g$ for $60 \mathrm{~min}$ and then deacetylated by vapor-phase acid hydrolysis with $6 \mathrm{~N} \mathrm{HCl}(1 \mathrm{~mL})$ under $\mathrm{N}_{2}$ at $110^{\circ} \mathrm{C}$ for $24 \mathrm{~h}$. Acid hydrolysates were freeze-dried in a SpeedVac (Labconco, Kansas City, MO) after addition of 12.5 
$\mu \mathrm{L}$ of $0.4 \mathrm{~m} M$ methionine sulfone $\left(\mathrm{MetSO}_{2}\right)$ and 12.5 $\mu \mathrm{L}$ of $0.4 \mathrm{mM}$ norleucine as internal standards. The dried samples were resolubilized in methanol, sodium acetate, and triethylamine $(10 \mu \mathrm{L} ; 2: 2: 1)$ and redried in the SpeedVac before they were derivatized with phenylisothiocyanate, freeze-dried, and subjected to HPLC analysis using Waters 2695 separation module with a Waters 2487 absorbance detector (Milford, MA).

\section{Calculations and Statistical Analysis}

Milk protein efficiency (MPE) was calculated as:

$$
\begin{aligned}
\mathrm{MPE}= & \text { Daily milk protein yield }(\mathrm{kg}) / \\
& \text { Daily } \mathrm{CP} \text { intake }(\mathrm{kg}),
\end{aligned}
$$

where daily $\mathrm{CP}$ intake included $\mathrm{CP}$ from feed plus infused AA. Feed, milk production, and milk composition data from the last $3 \mathrm{~d}$ of each infusion period were averaged and used for statistical analysis. Plasma samples for AA and 3-methylhistidine determination were pooled for each cow by period before analysis. Significance of treatment effects on milk component content $(\%)$ and yield $(\mathrm{kg} / \mathrm{d})$, feed and nutrient intake $(\mathrm{kg} / \mathrm{d})$, MPE, and plasma AA and 3-methylhistidine concentrations were tested with the following statistical model using the MIXED procedure of SAS 9.1 (SAS Inst. Inc., Cary, NC).

$$
Y_{i j k}=\mu+T_{i}+P_{j}+C_{k}+e_{i j k},
$$

where $Y_{i j k}=$ response variable value of the $k$ th cow subjected to the $i$ th treatment in the jth period, $\mu=$ the mean, $T_{i}=$ fixed effect of the $i$ th treatment $(i=$ $\mathrm{ML}, \mathrm{ML}+\mathrm{BCAA}$, and $\mathrm{CONT}), P_{j}=$ random effect of the $j$ th treatment period $(j=1,2$, and 3$), C_{k}=$ random effect of the $k$ th cow, and $e_{i j k}=$ random error assumed to be independent and identically distributed from a normal distribution with a mean of 0 and a variance of $\sigma^{2}\left[\sim \mathrm{N}\left(0, \mathbf{I} \sigma_{e}^{2}\right)\right]$. Period $\times$ treatment interactions were initially included and found to be very small, and were accordingly excluded in the final analyses. Multiple comparisons between treatments were carried out with the Tukey-Kramer adjustments test. Carryover effects of treatments were tested using the same model on the dependent variables measured during the noninfusion periods preceding each infusion period. No differences were found for lactation performance dependent variables between the 3 noninfusion periods; the data are not presented.

\section{RESULTS AND DISCUSSION}

The objective of the present study was to test the effects of BCAA on milk protein synthesis when methionine and lysine supply requirements were met or exceeded in high-producing dairy cows fed a corn-based diet. Amino acids were supplemented via jugular infusion rather than by postruminal infusion because jugular cannulation can be easily carried out, and it eliminates uncertainties of digestion and gastrointestinal metabolism of AA, ensuring that all of the infused AA enter the general circulation and are available for delivery to the mammary glands. Schei et al. (2007) observed significantly greater milk protein synthesis for jugular infusion of AA than that for postruminal infusion of AA, although Aikman et al. (2002) did not.

\section{Diet, Predicted EAA Supply, and DM and Nutrient Intake}

Ingredient composition of the basal diet is given in Table 1. Two-thirds of the experimental diet was composed of corn-based ingredients: corn silage (39.6\%), ground corn grain $(18.0 \%)$, and dry corn distillers grains with solubles (9.0\%). Although the diet was formulated to exceed metabolizable energy and essential AA other than the BCAA in CPMDairy 3.0, at mean DMI (23.9 $\mathrm{kg} / \mathrm{d}$ ), it supplied only 95 and $94 \%$ of NRC (2001) predicted net energy for lactation and MP requirements, respectively. Table 2 presents predicted duodenal flows of digestible EAA (NRC, 2001) from the basal diet at mean dietary intake and the mean daily methionine, lysine, and BCAA infusion rates $(\mathrm{g} / \mathrm{d})$. Estimates for duodenal flows of digestible lysine and methionine from the basal diet respectively were 6.1 and $1.8 \% \mathrm{MP}$, which is considerably less than the corresponding target values for lysine $(7.2 \%)$ and methionine $(2.4 \%)$ to maximize milk protein synthesis in dairy cows (NRC, 2001). This suggests that lysine and methionine were both limiting for milk protein synthesis. Jugular infusions of lysine $(21 \mathrm{~g} / \mathrm{d})$ and methionine $(12 \mathrm{~g} / \mathrm{d})$ were predicted (NRC 2001) to increase the total digestible lysine and methionine to 6.8 and $2.3 \% \mathrm{MP}$, respectively.

Dry matter intake averaged $23.9 \mathrm{~kg} / \mathrm{d}$ and was similar across treatment groups (Table 3 ). Given the short-term duration of the infusion treatments, treatments were not expected to alter DMI. Donkin et al. (1989) and Armentano et al. (1997) also observed nonsignificant changes in DMI when dairy cows were fed ruminally protected methionine (11.5 and $15.0 \mathrm{~g} / \mathrm{d}$, respectively) and lysine (14.7 and $40.0 \mathrm{~g} / \mathrm{d}$, respectively) in experimental diets with 16.4 and $19.5 \% \mathrm{CP}$, respectively. Although methi- 
Table 2. Digestible essential AA (EAA) flows as predicted by NRC (2001) from the basal diet at observed mean DMI, mean infused AA, and total digestible AA expressed as grams per day and percentages of metabolizable protein (\% of MP) of cows infused with saline (CTL), methionine and lysine (ML), and methionine and lysine plus branched-chain AA (ML+BCAA)

\begin{tabular}{|c|c|c|c|c|c|c|c|c|}
\hline EAA & $\begin{array}{l}\text { Diet }^{1} \\
\text { (g/d) }\end{array}$ & $\begin{array}{c}\text { CTL } \\
\% \text { of } \\
\text { MP }\end{array}$ & \multicolumn{3}{|c|}{ ML } & \multicolumn{3}{|c|}{$\mathrm{ML}+\mathrm{BCAA}$} \\
\hline His & 59 & 2.2 & & 59 & 2.2 & & 59 & 2.1 \\
\hline Ile & 126 & 4.7 & & 126 & 4.7 & 14 & 140 & 5.1 \\
\hline Leu & 236 & 8.9 & & 236 & 8.8 & 32 & 268 & 9.7 \\
\hline Phe & 132 & 5.0 & & 132 & 5.0 & & 132 & 4.8 \\
\hline Thr & 125 & 4.7 & & 125 & 4.7 & & 125 & 4.6 \\
\hline Total EAA ${ }^{2}$ & 1,154 & & 33 & 1,187 & & 91 & 1,245 & \\
\hline
\end{tabular}

${ }^{1}$ Digestible RUP and microbial CP.

${ }^{2}$ Except Trp.

onine supplementation can cause decreased feed intake, presumably due to an AA imbalance, such negative effects are not consistent across studies. For example, Robinson et al. (2000) observed a significant decrease in DMI in response to an abomasal infusion of $16.0 \mathrm{~g} / \mathrm{d}$ methionine when cows were fed a corn and timothy silage diet with $14.4 \%$ CP, whereas Varvikko et al. (1999) did not observe any negative effects on DMI when 40 $\mathrm{g} / \mathrm{d}$ methionine was infused abomasally in cows fed a grass silage diet with $14.2 \%$ CP. Dry matter intake was also unaffected by infusion of BCAA (Table 3). These results are in agreement with the observations of Korhonen et al. (2002) and Huhtanen et al. (2002) when BCAA or leucine were infused into dairy cows fed grass silage diets. Weekes et al. (2006) also observed no significant change in DMI between abomasal infusion of an AA mix devoid of BCAA and abomasal infusion of a complete AA mix.

\section{Milk Yield and Milk Components}

High-producing cows (greater than $45 \mathrm{~kg} / \mathrm{d}$ ) in early lactation (mean of 43 DIM) were chosen for the study to maximize the daily requirement for $\mathrm{AA}$ and provide

Table 3. Effects of saline (CTL), Met and Lys (ML), and Met, Lys plus branched-chain AA (ML+BCAA) infusion treatments on intake measures, milk protein and milk component measures, and milk protein efficiency

\begin{tabular}{|c|c|c|c|c|c|}
\hline \multirow[b]{2}{*}{ Variable } & \multicolumn{3}{|c|}{ LSM } & \multirow[b]{2}{*}{ SEM } & \multirow[b]{2}{*}{$P$-value } \\
\hline & CTL & ML & $\mathrm{ML}+\mathrm{BCAA}$ & & \\
\hline \multicolumn{6}{|l|}{ Intake } \\
\hline DM intake $(\mathrm{kg} / \mathrm{d})$ & 23.8 & 23.5 & 24.4 & 1.04 & 0.795 \\
\hline Dietary $\mathrm{CP}$ intake $(\mathrm{kg} / \mathrm{d})$ & 3.83 & 3.79 & 3.92 & 0.19 & 0.820 \\
\hline Infused AA (g/d) & $0.00^{\mathrm{a}}$ & $32.7^{\mathrm{b}}$ & $91.0^{\mathrm{c}}$ & 0.61 & $<0.001$ \\
\hline Total CP intake $(\mathrm{kg} / \mathrm{d})$ & 3.83 & 3.82 & 4.01 & 0.19 & 0.592 \\
\hline \multicolumn{6}{|l|}{ Milk production } \\
\hline Milk yield (kg/d) & 51.7 & 52.9 & 53.8 & 2.65 & 0.420 \\
\hline Protein yield $(\mathrm{kg} / \mathrm{d})$ & $1.39^{\mathrm{a}}$ & $1.52^{\mathrm{b}}$ & $1.51^{\mathrm{b}}$ & 0.07 & 0.063 \\
\hline Protein $(\%)$ & $2.71^{\mathrm{a}}$ & $2.88^{\mathrm{b}}$ & $2.83^{\mathrm{b}}$ & 0.06 & 0.009 \\
\hline Fat yield $(\mathrm{kg} / \mathrm{d})$ & 1.31 & 1.38 & 1.31 & 0.09 & 0.803 \\
\hline Fat $(\%)$ & 2.57 & 2.61 & 2.46 & 0.18 & 0.681 \\
\hline Lactose yield (kg/d) & 2.46 & 2.53 & 2.54 & 0.12 & 0.569 \\
\hline Lactose (\%) & 4.77 & 4.80 & 4.74 & 0.07 & 0.208 \\
\hline MUN yield (g/d) & 6.43 & 6.29 & $5.85^{*}$ & 0.47 & 0.181 \\
\hline MUN content $(\mathrm{mg} / \mathrm{dL})$ & $12.4^{\mathrm{a}}$ & $11.8^{\mathrm{a}}$ & $10.9^{\mathrm{b}}$ & 0.70 & 0.006 \\
\hline \multicolumn{6}{|l|}{ Efficiency } \\
\hline Milk protein efficiency $^{1}$ & 0.37 & 0.40 & 0.38 & 0.02 & 0.325 \\
\hline
\end{tabular}

${ }^{a-c}$ Different letters within a row indicate significantly different LSM $(P<0.05)$.

${ }^{1}$ Milk protein efficiency $=$ milk protein yield $(\mathrm{kg} / \mathrm{d}) /$ total $\mathrm{CP}$ intake $(\mathrm{kg} / \mathrm{d})$.

*Tended to decrease $(P=0.08)$ compared with that of CTL. 
as responsive a model as possible. Milk yield was not affected by the AA infusion treatments and averaged $52.8 \mathrm{~kg} / \mathrm{d}$ across treatments (Table 3 ). These results are similar to previous observations (Donkin et al., 1989; Lynch et al., 1991; Aldrich et al., 1993; Ouellet et al., 2003; Rulquin and Pisulewski, 2006). In the present study, cows that received different treatments did not significantly differ in content $(2.55 \%)$ and yield $(1.33$ $\mathrm{kg} / \mathrm{d}$ ) of milk fat. This is consistent with the literature often reporting small, nonsignificant increases in fat yield and content in response to AA supplementation.

Amino acid infusions significantly affected milk protein yield and protein content $(P=0.063)$ and protein content $(P=0.009$; Table 3$)$. Cows infused with ML produced $130 \mathrm{~g}$ more milk protein $(P=0.042)$ and had milk with $0.17 \%$ units greater milk protein content $(P=0.009)$ than did cows infused with saline. Several studies have shown that supplementation of methionine and lysine, either separately or together, significantly improved milk protein synthesis in dairy cows fed corn-based diets (Donkin et al., 1989; Armentano et al., 1997; Noftsger and St-Pierre, 2003; Weekes et al., 2006). As the common experimental diet of the present study was predicted to be responsive to methionine and lysine supply when assessed as a percentage of MP, the observed milk protein responses were consistent with model predictions. Although ML+BCAA also significantly increased milk protein yield (1.51 vs. $1.39 \mathrm{~kg} / \mathrm{d}, P=0.042)$ and milk protein content $(2.83$ vs. $2.71 \%, P=0.024$ ) compared with CTL treatment, no significant differences in either measure were found when compared with the ML treatment. This indicates that enhanced milk protein synthesis associated with the ML+BCAA treatment was due solely to provision of methionine and lysine with no effect of BCAA. Hopkins et al. (1994), Korhonen et al. (2002), and Weekes et al. (2006) also reported nonsignificant effects of BCAA supplementations on milk protein synthesis in dairy cows, but Rulquin and Pisulewski (2006) observed significant milk protein yield responses when 40 g leucine/d or more was duodenally infused into cows. Milk protein contents of cows infused with 80 and 120 $\mathrm{g} / \mathrm{d}$ of leucine were similar to that of $40 \mathrm{~g} / \mathrm{d}$, suggesting that the leucine requirement for maximum milk protein synthesis was met with the dose of $40 \mathrm{~g} / \mathrm{d}$ for those dietary circumstances (Rulquin and Pisulewski, 2006). In Rulquin and Pisulewski (2006), estimated duodenal flows of digestible valine, isoleucine, and leucine from the experimental diet were $4.5,4.1$, and $6.5 \%$ of MP, respectively, and less than that of the present study (5.3, 4.7, and $8.9 \%$ respectively; Table 2$)$. When Rulquin and Pisulewski (2006) infused $40 \mathrm{~g}$ of leucine/d, duodenal flow of digestible leucine increased to $8.9 \%$ of
MP, which is equivalent to the mean predicted digestible leucine from the basal diet of the present study. These results would indicate that the basal diet of the present study supplied sufficient leucine for maximum milk protein synthesis and may explain the lack of a response to infused BCAA.

Infusion of ML+BCAA decreased MUN yield and MUN content by $9(P=0.080)$ and $12 \%(P=0.002)$, respectively, compared with the saline infusion (Table 3). Interestingly, MUN contents of ML+BCAA cows were significantly less $(P=0.035)$ than that of ML cows. Milk urea nitrogen concentration is considered to be a useful tool for monitoring nitrogen utilization efficiency of dairy cows (Godden et al., 2001). Lower MUN concentrations are indicative of improved wholebody $\mathrm{N}$ utilization efficiency (Broderick et al., 2008), suggesting that more dietary protein was utilized to synthesize protein in the body (i.e., milk and muscle protein). Significantly decreased MUN concentrations without increased milk protein synthesis associated with the ML+BCAA treatment suggests that infusion of BCAA promoted more muscle protein synthesis than did the ML treatment. Because BCAA are well known to stimulate muscle protein synthesis (Escobar et al., 2006), the observed improvement in whole-body protein synthesis for BCAA infusion could presumably be associated with increased muscle protein synthesis.

\section{Milk Protein Efficiency}

Poor conversion efficiencies of dietary protein to productive proteins (i.e., milk and muscle) in dairy cows lead to significant losses of $\mathrm{N}$ in feces and urine. Dairy farm waste has been recognized as a critical source of environmental pollution (EPA, 2004; Cyriac et al., 2008). Improving efficiency of dietary protein utilization for milk protein synthesis is, therefore, of great importance for decreasing the negative effects of dairy farm waste on the environment. The milk protein efficiencies presented in Table 3 were calculated as milk protein yield $(\mathrm{kg} / \mathrm{d})$ divided by total $\mathrm{CP}$ intake $(\mathrm{kg} / \mathrm{d})$. Total CP intake consisted of dietary $\mathrm{CP}$ and infused AA. Protein efficiency averaged 0.38 , which is greater than values commonly reported in the literature, and was numerically increased for the ML treatment $(P=$ 0.140) as compared with CTL (Table 3). Nadeau et al. (2007) reported milk protein efficiencies ranging from 0.18 to 0.40 in dairy cows fed diets containing 14 to $18 \% \mathrm{CP}$ and producing 13 to $57 \mathrm{~kg} / \mathrm{d} \mathrm{FCM}$, and efficiency improved as milk production increased. Socha et al. (2005) also observed efficiency increase from 0.29 to 0.32 when supplementing an $18.5 \%$-CP diet with rumen-protected methionine and lysine. 
Table 4. Effects of saline (CTL), Met and Lys (ML), and Met, Lys plus branched-chain AA (ML+BCAA) infusion treatments on plasma essential amino acid (EAA, $\mu \mathrm{mol} / \mathrm{L})$ and 3-methylhistidine $(3 \mathrm{M}-\mathrm{His}, \mu \mathrm{mol} / \mathrm{L})$ concentrations

\begin{tabular}{lccccc}
\hline & \multicolumn{5}{c}{ LSM } \\
AA & CTL & ML & ML+BCAA & SEM & $P$-value \\
\cline { 2 - 4 } Arg & 87.9 & 71.4 & 79.4 & 8.98 & 0.454 \\
Ile & $110^{\mathrm{a}}$ & $91.6^{\mathrm{b}}$ & $107^{\mathrm{a}}$ & 8.33 & 0.034 \\
Leu & 182 & 179 & 205 & 10.9 & 0.214 \\
Lys & $69.2^{\mathrm{a}}$ & $81.1^{\mathrm{b}}$ & $72.6^{\mathrm{ab} *}$ & 2.71 & 0.029 \\
Met & $23.3^{\mathrm{a}}$ & $31.1^{\mathrm{b}}$ & $26.7^{\mathrm{a} * *}$ & 1.81 & 0.005 \\
Phe & 54.2 & 49.7 & 52.6 & 3.80 & 0.663 \\
Thr & 103 & 106 & 108 & 2.72 & 0.241 \\
Trp & 31.6 & 32.8 & 33.2 & 3.11 & 0.875 \\
Val & 237 & 230 & 257 & 19.0 & 0.281 \\
3M-His & 10.4 & 11.6 & $11.9^{* *}$ & 0.80 & 0.144 \\
\hline
\end{tabular}

${ }^{\mathrm{a}, \mathrm{b}}$ Different letters within a row indicate significantly different LSM $(P<0.05)$.

*Tended $(P<0.10)$ to be different from ML; **tended $(P<0.10)$ to be different from CTL.

\section{Plasma Concentrations of EAA}

Least squares means for plasma EAA concentrations are given in Table 4. Plasma methionine concentrations significantly increased $(P=0.001)$ by $33 \%$ when cows were infused with ML. Infusion of ML increased plasma lysine concentrations by $17 \%$ compared with that of saline infusions $(P=0.011$; Table 4$)$. Plasma AA concentrations reflect the balance between AA supply and utilization (Meijer et al., 1995). Plasma methionine and lysine concentrations of cows infused with ML+BCAA were numerically intermediate between CTL and ML treatments. Plasma methionine and lysine concentration of ML+BCAA tended $(P=0.072$ and $P=051$, respectively) to decrease compared with that of $\mathrm{ML}$, indicating synthesis of non-mammary proteins may have been stimulated, because milk protein synthesis was approximately equal between the 2 treatments.

Donkin et al. (1989) reported no changes in plasma EAA except methionine and lysine when cows were fed rumen-protected methionine $(15 \mathrm{~g} / \mathrm{d})$ and lysine (40 $\mathrm{g} / \mathrm{d}$ ). In this study, jugular infusion of ML did not cause any changes in plasma concentrations of other EAA except isoleucine (Table 4). Plasma isoleucine concentrations decreased by $17 \%$ in ML cows $(P=0.015)$ compared with CTL. Consistent with this observation, Blum et al. (1999) and Varvikko et al. (1999) observed similar declines in plasma isoleucine in dairy cows supplemented with ruminally protected and abomasally infused methionine, respectively. Jugular infusion of isoleucine in ML+BCAA increased plasma isoleucine to a similar level as CTL, and significantly higher than that from $\mathrm{ML}$ treatment $(P=0.033)$. Leucine and valine concentrations were numerically increased by the ML +BCAA infusion. However, these increases in plasma BCAA concentrations were not associated with increased milk protein synthesis. In contrast to these observations, Rulquin and Pisulewski (2006) observed that daily duodenal infusion of $40 \mathrm{~g}$ of leucine increased plasma leucine concentration by $55 \%$. Moreover, infusion of a BCAA-deficient AA mixture resulted in $58 \%$ plasma BCAA decrease compared with that of a complete AA mix infusion (Weekes et al., 2006). Both of these prior studies used low-protein diets (12.5 and $9.0 \%$ of $\mathrm{CP}$, respectively) which presumably would have caused a more pronounced BCAA deficiency than the diet in the current study.

High-producing dairy cows can mobilize AA from muscle to compensate for deficiencies in dietary AA supply compared with demand for milk protein synthesis. 3-Methylhistidine (3M-His) is formed by methylation of histidine in actin and myosin (Blum et al., 1985). Moreover, upon release following actin and myosin degradation, 3M-His is not subjected to tissue metabolism and directly enters the systemic circulation. Therefore, it is a sensitive measure of muscle breakdown (Akamatsu et al., 2007). Two forms of 3M-His exist: N-acetyl-3M-His and the deacetylated parent compound. The proportion of these 2 forms in plasma varies widely across species (i.e., $5 \% \mathrm{~N}$-acetyl-3M-His in adult humans compared with $80-90 \%$ in rats; Kuhl et al., 1996). To detect 3M-His using classical methods, it must be in the deacetylated form, which is accomplished by acid hydrolysis. Average $3 \mathrm{M}$-His concentrations of $11.3 \mu M$ were observed in the present study. These concentrations fall within the range of blood 3M-His concentrations (7.1 to $14.0 \mu M$ ) reported in the literature (Blum et al., 1985; Akamatsu et al., 2007) for dairy cows at peak lactation. In Akamatsu et al. (2007), serum samples were subjected to acid hydrolysis before HPLC analysis, whereas Blum et al. (1985) used a radioimmunoassay system to measure plasma 3M-His concentrations. Along with the milk 
protein yield and content, ML infusion and ML+BCAA were associated with a $13 \%$ increase in plasma $3 \mathrm{M}-\mathrm{His}$ compared with that of CTL (Table 4). Increased milk protein synthesis for methionine and lysine supplementation appeared to be supported by AA mobilized from muscle during this short-term experiment. In the longer term, cows could meet the energy and AA requirements for similar levels of increased milk protein synthesis by increasing DMI.

\section{CONCLUSIONS}

Results of this study show that supplementation of a corn-based diet with methionine plus lysine resulted in significantly increased milk protein yield and content in high-producing dairy cows. When methionine and lysine were not limiting for milk protein synthesis, BCAA infusion did not increase milk protein synthesis under the dietary circumstances of the present study. Significantly decreased MUN of ML+BCAA-infused cows suggest that BCAA infusion may have promoted the synthesis of other body tissue proteins.

\section{ACKNOWLEDGMENTS}

This material is based upon work supported by grants from Venture Milling, Inc. and the Cooperative State Research, Education and Extension Service, USDA, under Project No. NC-1040. The authors acknowledge general departmental funding provided by the Virginia State Dairymen's Association, and the Virginia Tech Dairy Complex crew for help in conducting the study. The contributions of Chris Umberger, Agustin Rius, and Kathryn Price at Virginia Tech (Blacksburg) are gratefully acknowledged. Any opinions, findings, conclusions, or recommendations expressed in this publication are those of the authors and do not necessarily reflect the view of the USDA, the Virginia State Dairymen's Association, or Venture Milling, Inc.

\section{REFERENCES}

Aikman, P. C., C. K. Reynolds, D. J. Humphries, D. E. Beever, and J. C. MacRae. 2002. Milk protein response to abomasal or mesenteric vein essential amino acid infusion in lactating dairy cows. J. Dairy Sci. 85:1079-1084.

Akamatsu, H., Y. Saitoh, M. Serizawa, K. Miyake, Y. Ohba, and K. Nakashima. 2007. Changes of serum 3-methylhistidine concentration and energy-associated metabolites in dairy cows with ketosis. J. Vet. Med. Sci. 69:1091-1093.

Aldrich, J. M., L. D. Muller, and G. A. Varga. 1993. Effect of somatotropin administration and duodenal infusion of methionine and lysine on lactational performance and nutrient flow to the small intestine. Br. J. Nutr. 69:49-58.

AOAC. 1997. Official Methods of Analysis. AOAC Intl., Gaithersburg, MD.
Armentano, L. E., S. J. Bertics, and G. A. Ducharme. 1997. Response of lactating cows to methionine or methionine plus lysine added to high protein diets based on alfalfa and heated soybeans. J. Dairy Sci. 80:1194-1199.

Blum, J. W., R. D. Bruckmaier, and H. Jans. 1999. Rumen-protected methionine fed to dairy cows: Bioavailability and effects on plasma amino acid pattern and plasma metabolite and insulin concentrations. J. Dairy Sci. 82:1991-1998.

Blum, J. W., T. Reding, F. Jans, M. Wanner, M. Zemp, and K. Bachmann. 1985. Variations of 3-methylhistidine in blood of dairy cows. J. Dairy Sci. 68:2580-2587.

Bolster, D. R., L. S. Jefferson, and S. R. Kimball. 2004. Regulation of protein synthesis associated with skeletal muscle hypertrophy by insulin-, amino acid- and exercise-induced signalling. Proc. Nutr. Soc. 63:351-356.

Broderick, G. A., M. J. Stevenson, R. A. Patton, N. E. Lobos, and J. J. Olmos Colmenero. 2008. Effect of supplementing rumen-protected methionine on production and nitrogen excretion in lactating dairy cows. J. Dairy Sci. 91:1092-1102.

Cho, J., T. R. Overton, C. G. Schwab, and L. W. Tauer. 2007. Determining the amount of rumen-protected methionine supplement that corresponds to the optimal levels of methionine in metabolizable protein for maximizing milk protein production and profit on dairy farms. J. Dairy Sci. 90:4908-4916.

Cyriac, J., A. G. Rius, M. L. McGilliard, R. E. Pearson, B. J. Bequette, and M. D. Hanigan. 2008. Lactation performance of midlactation dairy cows fed ruminally degradable protein at concentrations lower than national research council recommendations. J. Dairy Sci. 91:4704-4713.

Donkin, S. S., G. A. Varga, T. F. Sweeney, and L. D. Muller. 1989. Rumen-protected methionine and lysine: Effects on animal performance, milk protein yield, and physiological measures. J. Dairy Sci. 72:1484-1491.

El-Kadi, S. W., R. L. Baldwin VI, N. E. Sunny, S. L. Owens, and B. J. Bequette. 2006. Intestinal protein supply alters amino acid, but not glucose, metabolism by the sheep gastrointestinal tract. J. Nutr. 136:1261-1269.

EPA. 2004. National emission inventory-Ammonia emissions from animal husbandry operations. USEPA, Washington, DC.

Escobar, J., J. W. Frank, A. Suryawan, H. V. Nguyen, S. R. Kimball, L. S. Jefferson, and T. A. Davis. 2006. Regulation of cardiac and skeletal muscle protein synthesis by individual branched-chain amino acids in neonatal pigs. Am. J. Physiol. Endocrinol. Metab. 290:E612-E621.

Godden, S. M., K. D. Lissemore, D. F. Kelton, K. E. Leslie, J. S. Walton, and J. H. Lumsden. 2001. Relationships between milk urea concentrations and nutritional management, production, and economic variables in Ontario dairy herds. J. Dairy Sci. 84:11281139.

Griinari, J. M., M. A. McGuire, D. A. Dwyer, D. E. Bauman, D. M. Barbano, and W. A. House. 1997. The role of insulin in the regulation of milk protein synthesis in dairy cows. J. Dairy Sci. 80:2361-2371.

Guinard, J., and H. Rulquin. 1994. Effects of graded amounts of duodenal infusions of lysine on the mammary uptake of major milk precursors in dairy cows. J. Dairy Sci. 77:3565-3576.

Hillgartner, F. B., A. S. Williams, J. A. Flanders, D. Morin, and R. J. Hansen. 1981. Myofibrillar protein degradation in the chicken. 3 -Methylhistidine release in vivo and in vitro in normal and genetically muscular-dystrophic chickens. Biochem. J. 196:591-601.

Hopkins, B. A., A. H. Rakes, T. E. Daniel, C. A. Zimmerman, and W. J. Croom Jr. 1994. Effects of intraperitoneal L-leucine, L-isoleucine, L-valine, and L-arginine on milk fat depression in early lactation cows. J. Dairy Sci. 77:1084-1092.

Huhtanen, P., A. Vanhatalo, and T. Varvikko. 2002. Effects of abomasal infusions of histidine, glucose, and leucine on milk production and plasma metabolites of dairy cows fed grass silage diets. J. Dairy Sci. 85:204-216.

Korhonen, M., A. Vanhatalo, and P. Huhtanen. 2002. Evaluation of isoleucine, leucine, and valine as a second-limiting amino acid for 
milk production in dairy cows fed grass silage diet. J. Dairy Sci. 85:1533-1545.

Kuhl, D. A., J. T. Methvin, and R. N. Dickerson. 1996. Standardization of acid hydrolysis procedure for urinary 3-methylhistidine determination by high-performance liquid chromatography. J Chromatogr. B Biomed. Appl. 681:390-394.

Li, P., D. A. Knabe, S. W. Kim, C. J. Lynch, S. M. Hutson, and G. Wu. 2009. Lactating porcine mammary tissue catabolizes branched-chain amino acids for glutamine and aspartate synthesis. J. Nutr. 139:1502-1509.

Lynch, G. L., T. H. Klusmeyer, M. R. Cameron, J. H. Clark, and D. R. Nelson. 1991. Effects of somatotropin and duodenal infusion of amino acids on nutrient passage to duodenum and performance of dairy cows. J. Dairy Sci. 74:3117-3127.

Mackle, T. R., D. A. Dwyer, and D. E. Bauman. 1999. Effects of branched-chain amino acids and sodium caseinate on milk protein concentration and yield from dairy cows. J. Dairy Sci. 82:161171

McGuire, M. A., J. M. Griinari, D. A. Dwyer, and D. E. Bauman. 1995. Role of insulin in the regulation of mammary synthesis of fat and protein. J. Dairy Sci. 78:816-824.

Meijer, G. A., J. Van der Meulen, J. G. Bakker, C. J. Van der Koelen, and A. M. Van Vuuren. 1995. Free amino acids in plasma and muscle of high yielding dairy cows in early lactation. J. Dairy Sci. 78:1131-1141

Moser, S. A., M. D. Tokach, S. S. Dritz, R. D. Goodband, J. L. Nelssen, and J. A. Loughmiller. 2000. The effects of branched-chain amino acids on sow and litter performance. J. Anim. Sci. 78:658-667.

Moshel, Y., R. E. Rhoads, and I. Barash. 2006. Role of amino acids in translational mechanisms governing milk protein synthesis in murine and ruminant mammary epithelial cells. J. Cell. Biochem. 98:685-700.

Nadeau, E., J.-E. Englund, and A. H. Gustafsson. 2007. Nitrogen efficiency of dairy cows as affected by diet and milk yield. Livest. Sci. 111:45-56.

Noftsger, S., and N. R. St-Pierre. 2003. Supplementation of methionine and selection of highly digestible rumen undegradable protein to improve nitrogen efficiency for milk production. J. Dairy Sci. 86:958-969.

NRC. 2001. Nutrient Requirements of Dairy Cattle. 7th ed. National Academy Press, Washington, DC.

Ouellet, D. R., H. Lapierre, and J. Chiquette. 2003. Effects of corn silage processing and amino acid supplementation on the performance of lactating dairy cows. J. Dairy Sci. 86:3675-3684.
Richert, B. T., R. D. Goodband, M. D. Tokach, and J. L. Nelssen 1997. Increasing valine, isoleucine, and total branched-chain amino acids for lactating sows. J. Anim. Sci. 75:2117-2128.

Robinson, P. H., W. Chalupa, C. J. Sniffen, W. E. Julien, H. Sato, T. Fujieda, T. Ueda, and H. Suzuki. 2000. Influence of abomasal infusion of high levels of lysine or methionine, or both, on ruminal fermentation, eating behavior, and performance of lactating dairy cows. J. Anim. Sci. 78:1067-1077.

Rulquin, H., and P. M. Pisulewski. 2006. Effects of graded levels of duodenal infusions of leucine on mammary uptake and output in lactating dairy cows. J. Dairy Res. 73:328-339.

Schei, I., A. Danfaer, I. A. Boman, and H. Volden. 2007. Post-ruminal or intravenous infusions of carbohydrates or amino acids to dairy cows 1. Early lactation. Animal 1:501-514.

Shimomura, Y., Y. Yamamoto, G. Bajotto, J. Sato, T. Murakami, N. Shimomura, H. Kobayashi, and K. Mawatari. 2006. Nutraceutical effects of branched-chain amino acids on skeletal muscle. J. Nutr. 136:529S-532S.

Socha, M. T., D. E. Putnam, B. D. Garthwaite, N. L. Whitehouse, N. A. Kierstead, C. G. Schwab, G. A. Ducharme, and J. C. Robert. 2005. Improving intestinal amino acid supply of pre- and postpartum dairy cows with rumen-protected methionine and lysine. J. Dairy Sci. 88:1113-1126.

Van Soest, P. J., J. B. Robertson, and B. A. Lewis. 1991. Methods for dietary fiber, neutral detergent fiber, and nonstarch polysaccharides in relation to animal nutrition. J. Dairy Sci. 74:3583-3597.

Varvikko, T., A. Vanhatalo, T. Jalava, and P. Huhtanen. 1999. Lactation and metabolic responses to graded abomasal doses of methionine and lysine in cows fed grass silage diets. J. Dairy Sci. 82:2659-2673

Vyas, D., and R. A. Erdman. 2009. Meta-analysis of milk protein yield responses to lysine and methionine supplementation. J. Dairy Sci. 92:5011-5018.

Weekes, T. L., P. H. Luimes, and J. P. Cant. 2006. Responses to amino acid imbalances and deficiencies in lactating dairy cows. J. Dairy Sci. 89:2177-2187.

Wohlt, J. E., J. H. Clark, R. G. Derrig, and C. L. Davis. 1977. Valine, leucine, and isoleucine metabolism by lactating bovine mammary tissue. J. Dairy Sci. 60:1875-1882. 